\title{
Perancangan Dan Realisasi Sistem Transmisi Data GPS Menggunakan Teknologi SMS (Short Messaging Service) Sebagai Aplikasi Sistem Personal Tracking
}

\author{
DECY NATALI ANA \\ Jurusan Teknik Elektro (Institut Teknologi Nasional) \\ Email : decy@itenas.ac.id
}

\begin{abstract}
ABSTRAK
Berprinsip pada pengembangan teknologi dan aplikasi dari sistem penjejakan posisi (tracking), maka dibuatlah sistem personal tracking dengan mentransmisikan data GPS (Global Positioning System) dengan menggunakan teknologi SMS (Short Messaging Service) pada jaringan GSM (Global System for Mobile Communications) sebagai media transmisinya. Dengan sistem GPS akan diperoleh data garis lintang, serta garis bujur dari GPS receiver. Data tersebut akan diteruskan oleh mikrokontroler untuk dikirim ke ponsel pengamat melalui komunikasi SMS. Hasil pengujian menunjukkan bahwa device personal tracking berhasil mengirimkan data berupa IMEI, Tanggal satelit, waktu satelit, koordinat longitude, koordinat latitude, dan jumlah satelit yang berhasil ditangkap oleh device ke ponsel pengamat. Dari data koordinat tersebut pengamat dapat memantau posisi device personal tracking berada dengan bantuan aplikasi pendukung yaitu Google Maps.
\end{abstract}

Kata kunci: GPS, Personal Tracking, SMS, Google Maps.

\begin{abstract}
Base on technology and application development of tracking, personal tracking system was made by transmiting GPS (Global Positioning System) data using SMS (Short Messaging Service) technology with GSM (Global System for Mobile Communications) network as transmitter media. BY GPS system, we can get datas such as latitude and longitude of GPS receiver. Those datas will be processed by microcontroller to be sent from GSM/GPRS module to user cellular phone through SMS communication. The test result showed that the device can be sending datas such as IMEI, UTC date, UTC time, longitude coordinate, latitude coordinate, and number sattelite which detected by device to user's phonecell. From those coordinate, user can be monitoring the device's position with the Google Maps application.
\end{abstract}

Keywords: GPS, Personal Tracking, SMS, Google Maps. 


\section{PENDAHULUAN}

Sebuah sistem tracking yang umum digunakan adalah dengan menggunakan GPS (Global Positioning System). Karena dengan menggunakan GPS kita dapat mengetahui koordinat lintang dan koordinat bujur dari suatu tempat atau titik di permukaan bumi, sehingga dapat ditentukan posisi dari tempat ataupun titik tersebut. (Abidin,2000)

Posisi tersebut dapat ditentukan dengan menggunakan GPS receiver yang merupakan koordinat lintang dan bujur dari GPS receiver itu sendiri. GPS receiver akan memberikan data keluaran berupa data posisi (koordinat lintang dan bujur), waktu, kecepatan, serta arah dari GPS receiver tersebut. (Abidin,2000)

Pada penelitian ini dirancang sebuah sistem penjejakan mandiri (personal tracking) mempergunakan teknologi SMS sebagai media pengiriman paket data koordinat posisi. Mekanisme kerja sistem ini yakni jika posisi GPS receiver atau posisi device dan posisi pengamat berada di tempat yang berbeda, pengamat dapat mengetahui posisi GPS receiver dengan melakukan koneksi dengan GPS receiver tersebut guna mendapatkan data posisi. Setelah GPS receiver mempunyai data posisi dan pengamat ingin memperoleh posisi tersebut pada saat itu juga (real-time) maka dibutuhkan sebuah media guna pengiriman data posisi alat yang diinginkan oleh pengamat. Dalam hal ini dipergunakan sebuah teknologi yang sudah umum dipergunakan yakni teknologi SMS. Dengan teknologi ini data tersebut dapat sampai ke tempat pengamat berada tanpa pengamat harus menghampiri alat tersebut. Dengan penggunaan teknologi SMS maka device personal tracking perlu adanya penambahan modul yang berfungsi untuk mengirimkan data posisi layaknya sebuah ponsel. Dengan kata lain perancangan dan realisasi ini dimaksudkan guna mengadopsi kinerja ponsel yang diintegrasikan ke dalam perangkat tracking, sehingga dimanapun dan kapanpun selama device tracking tersebut aktif maka pengamat dapat memperoleh data posisi device tersebut dimanapun berada.

Satelit GPS mengelilingi bumi dua kali sehari dalam orbit yang amat presisi sambil memancarkan sinyal ke bumi. GPS receiver (kita sebut receiver saja) menerima informasi ini menggunakan metode Triangulasi untuk menghitung secara pasti di mana lokasi receiver. Pada dasarnya, receiver membandingkan timing dalam microsecond pulsa waktu dari sinyal yang ditransmisikan oleh satelit dengan timing pulsa waktu, yang diterima pada receiver dengan transmisi pseudorandom code. Perbedaan waktu inilah yang akan memberitahu receiver seberapa jauh dan arah satelit berada darinya. Setelah jarak diukur dengan sejumlah satelit GPS lainnya, receiver dapat menentukan posisinya dalam koordinat lintang dan bujur derajat.

Receiver harus mengunci paling tidak 3 satelit untuk menghitung posisi 2 dimensi (garis lintang dan garis bujur) dan lintasan pergerakan. Dengan 4 atau lebih satelit yang dapat di akses, receiver dapat menentukan posisi 3 dimensi (+ ketinggian). Posisi dari pengguna dapat ditentukan, receiver GPS dapat juga menentukan informasi lain seperti kecepatan, lintasan yang telah dilewati, jarak perjalanan yang sudah ditempuh, jarak ke tempat tujuan, waktu sunrise dan sunset dan lain sebagainya. Sinyal GPS mengandung tiga informasi yaitu kode pseudorandom, data ephemeris dan data almanak. Sinyal transmisi dari satelit GPS merupakan sinyal identifikasi satelit saat sedang mengirim informasi terhadap GPS receiver. Selanjutnya GPS receiver menghitung timing waktu rambatan gelombang dari satelite Navstar dengan menghitung selisih timing pulsa antara "pseudo random code" dari receiver GPS dengan sinyal yang identik dari satelit GPS Navstar. Kelebaran frekuensi (Bandwidth) yang dibutuhkan untuk mentransmisikan pseudo random code sekitar $1 \mathrm{MHz}$, sehingga 
transmisi sinyal GPS ditransmisikan pada gelombang $20 \mathrm{~cm}$ atau sekitar 1.2 - $1.5 \mathrm{GHZ}$. (trimble.com,2006)

Sistem penjejakan posisi (tracking) ini dibagi dalam dua bagian, yaitu bagian objek dan bagian tracking. Bagian objek terdiri dari GPS receiver, sistem mikrokontroler STM32, dan ponsel GSM. Sedangkan bagian tracking terdiri dari ponsel GSM dan PC (Personal Computer) atau notebook.

Bagian objek berfungsi untuk mengirimkan data GPS receiver dan bagian navigasi berfungsi untuk melakukan penjejakan posisi (tracking) GPS receiver tersebut. Namun, pembahasan pada tugas akhir ini lebih ditekankan pada bagian objek, yang meliputi penjelasan mengenai GPS receiver, mikrokontroler STM32L, deskripsi kerja sistem, perancangan hardware bagian objek, serta pengujian dan analisis sistem.

\section{METODOLOGI PENELITI AN}

\subsection{Spesifikasi Sistem}

Tabel 1. Spesifikasi Sistem Personal Tracking

\begin{tabular}{|c|c|c|c|c|}
\hline No. & Komponen & Fungsi & Tipe & Keterangan \\
\hline \multirow{3}{*}{1} & \multirow{3}{*}{$\begin{array}{l}\text { Modul GPS } \\
\text { receiver }\end{array}$} & \multirow{3}{*}{$\begin{array}{l}\text { Memproses sinyal-sinyal GPS yang } \\
\text { dipancarkan oleh satelit dan kemudian } \\
\text { merubah sinyal tersebut menjadi format } \\
\text { protokol NMEA } 0183\end{array}$} & \multirow{3}{*}{ FGMMOPA6B } & Power Supply 3.0 Volt - 4.3 Volt \\
\hline & & & & Frekuensi L1, $1575.42 \mathrm{MHz}$ \\
\hline & & & & $\begin{array}{l}\text { Akurasi Posisi : } 2.5-3.0 \text { meter } \\
\text { (Open Sky) }\end{array}$ \\
\hline \multirow{6}{*}{2} & \multirow{6}{*}{ Mikrokontroler } & \multirow{4}{*}{$\begin{array}{l}\text { Memperoses data NMEA yang berasal dari } \\
\text { GPS receiver menjadi format SMS } \\
\text { Format NMEA } 0183 \text { yang diproses hanya } \\
\text { tipe kalimat \$GPGAA dan \$GPRMC }\end{array}$} & \multirow{6}{*}{$\begin{array}{l}\text { ARM Cortex- } \\
\text { M3 STM32 }\end{array}$} & Power Supply 1.65 Volt - 3.6 Volt \\
\hline & & & & Memori Flash 256 Kbyte \\
\hline & & & & Memori RAM 32 Kbyte \\
\hline & & & & Memori EEPROM 8 Kbyte \\
\hline & & \multirow{2}{*}{$\begin{array}{l}\text { Memerintahkan modul GSM/GPRS guna } \\
\text { mengirim paket SMS ke pengamat serta } \\
\text { memerintahkan modul GSM/GPRS aktif } \\
\text { atau dalam mode sleep }\end{array}$} & & Memori backup register 128 byte \\
\hline & & & & $\begin{array}{l}\text { Komunikasi yang dipergunakan } \\
\text { USART (serial) }\end{array}$ \\
\hline \multirow{2}{*}{3} & \multirow{2}{*}{$\begin{array}{l}\text { Modul } \\
\text { GSM/GPRS }\end{array}$} & \multirow{2}{*}{$\begin{array}{l}\text { Mengirimkan data paket SMS hasil proses } \\
\text { pada mikrokontroler kepada pengamat } \\
\text { (user) }\end{array}$} & \multirow{2}{*}{$\begin{array}{l}\text { SimCom } \\
\text { 900D }\end{array}$} & Power Supply 3.4 Volt - 4.5 Volt \\
\hline & & & & Support Sim Card 1.8 Volt, 3 Volt \\
\hline 4 & Push Button & $\begin{array}{l}\text { Merupakan interrupt terhadap sistem, jika } \\
\text { terjadi hal diluar kendali pengguna } \\
\text { device. Dengan adanya penekatan } \\
\text { terhadap push button maka sistem akan } \\
\text { memberikan sinyal alert kepada } \\
\text { pengamat. }\end{array}$ & $\begin{array}{l}\text { Mini } \\
\text { Momentary } \\
\text { Tactile Button } \\
\text { Straight Push } \\
\text { Switch }\end{array}$ & $\begin{array}{l}\text { Push On (Active saat ada } \\
\text { penekanan) }\end{array}$ \\
\hline 5 & $\begin{array}{l}\text { Sumber } \\
\text { Tegangan }\end{array}$ & $\begin{array}{l}\text { Memberikan asupan tegangan ke sistem } \\
\text { tracking }\end{array}$ & $\begin{array}{l}\text { Panasonic } \\
\text { Evolta LR6EG }\end{array}$ & 1.5 Volt $\times 3$ \\
\hline 6 & Firmware & $\begin{array}{l}\text { Mengontrol alur sistem mulai kondisi ON } \\
\text { sampai OFF }\end{array}$ & RTOS COOS & $\begin{array}{l}\text { CoOS merupakan real time } \\
\text { Operating system berbasis kepada } \\
\text { prioritas kerja }\end{array}$ \\
\hline 7 & $\begin{array}{l}\text { Waktu } \\
\text { Pengiriman } \\
\text { Paket SMS ke } \\
\text { Pengamat }\end{array}$ & $\begin{array}{l}\text { Waktu yang diperlukan oleh device } \\
\text { mengirim paket SMS yang berisi data } \\
\text { koordinat posisi sampai ke pengamat } \\
\text { sehingga user mengetahui letak device }\end{array}$ & menit & $\begin{array}{l}\text { Interval pengiriman paket SMS per } \\
\pm 5 \text { menit, akan tetapi jika push } \\
\text { button ditekan, interval } \\
\text { pengiriman SMS berkisar } \pm 1-3 \\
\text { menit }\end{array}$ \\
\hline 8 & $\begin{array}{l}\text { Operator } \\
\text { Seluler }\end{array}$ & $\begin{array}{l}\text { Mengirimkan data SMS dari tracking } \\
\text { device ke pengamat }\end{array}$ & & $\begin{array}{l}\text { Sistem mempergunakan operator } \\
\text { Xl-axiata }\end{array}$ \\
\hline
\end{tabular}




\subsection{Perangkat Keras Sistem Personal Tracking}

Sistem tracking yang sedang dirancang memiliki beberapa bagian, yaitu modul GPS receiver, sistem minimum mikrokontroler ARM Cortex-M3 STM32, Modul GSM/GPRS, push button, serta catu daya. Blok diagram sistem dapat dilihat pada Gambar 1.

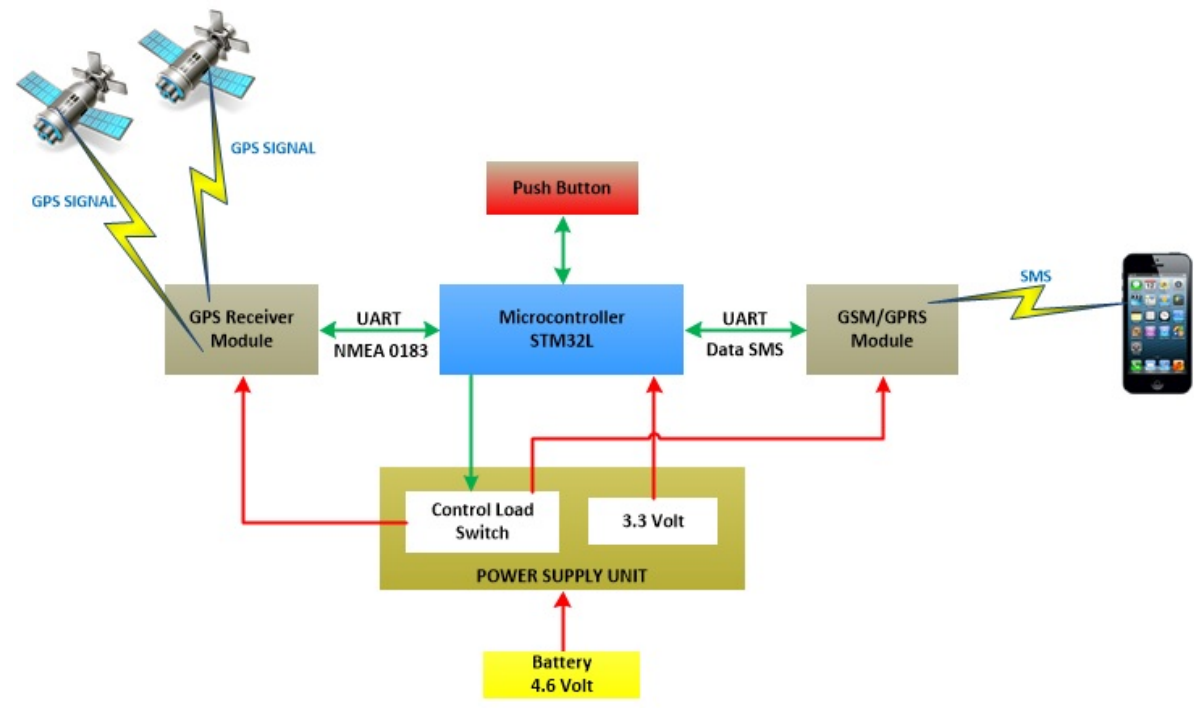

Gambar 1. Diagram Blok Sistem

Cara kerja sistem adalah sebagai berikut :

a. Personal tracking siap dijalankan setelah catu daya diaktifkan.

b. Pada bagian power supply terdapat control load switch yang fungsinya sebagai switch elektronik, kegunaan switch ini yakni untuk menonaktifkan atau mengaktifkan modul GPS dan modul GSM/GPRS. Mikrokontroler yang bertugas melakukan proses ini. Tracking versi ini control load switch hanya dipergunakan untuk modul GSM/GPRS saja, sedangkan modul GPS dibiarkan "on" agar proses akuisisi lebih cepat. Modul GSM/GPRS diaktifkan jika proses pengiriman SMS sedang, dan akan berlangsung, setelah proses pengiriman SMS telah dilakukan, modul GSM/GPRS akan dinonaktifkan.

c. Dengan mengunci minimum 3 sinyal dari satelit yang berbeda, maka GPS receiver dapat menghitung posisi tetap sebuah titik yaitu koordinat posisi lintang dan bujur (latitude dan longitude). Penguncian sinyal satelit yang ke-4 membuat GPS receiver dapat menghitung posisi ketinggian titik tersebut terhadap permukaan laut (altitude). (Prasimax Technology, 1994)

d. Data output yang dihasilkan dari proses perhitungan sinyal pada GPS receiver dinamakan NMEA 0183. NMEA 0183 ini merupakan standar kalimat laporan yang dikeluarkan oleh GPS receiver yang memiliki beberapa jenis kalimat yang didalamnya terdapat informasi koordinat lintang (latitude), bujur (longitude), ketinggian (altitude), standar UTC (UTC time), serta kecepatan (ground speed).(NMEA Ref.,2007)

e. Selanjutnya data output yang berupa NMEA 0183 tersebut dikirimkan ke mikrokontroler melalui USART (serial), dalam mikrokontroler inilah data NMEA -0183 diolah dan dipilah sesuai kebutuhan sistem. 
f. Mikrokontroler akan mengolah data GPS yang berupa NMEA, data yang berformat ASCII tersebut diubah menjadi format text yang fungsinya agar dapat dikenali oleh modul GSM/GPRS.

g. Dalam modul GSM/GPRS inilah data SMS tersebut dipersiapkan untuk dilakukan pengiriman ke handphone user yang kemudian user dapat mengetahui dimana keberadaan device personal tracking tersebut.

h. Push button jika ditekan, sistem akan mengalami interrupt dan kemudian sistem akan memberikan sinyal kepada pengamat bahwa sedang terjadi sesuatu yang dialami oleh pembawa device. Sinyal alert ini juga berupa SMS hanya saja format yang dikirimkan berbeda.

i. Terdapat tiga jenis format SMS yang nantinya akan diterima oleh pengamat, yakni format \$I NIT (keberhasilan awal pada saat inisialisasi sistem), \$CHECKI N (format SMS yang normal diterima pengamat sesuai rentang waktu yang ditentukan), dan \$PANI C (format SMS bilamana push button ditekan).

\subsection{Perangkat Lunak Sistem Personal Tracking}

Perangkat lunak pada sistem ini mempergunakan real time operating system CoOS. Dasar pemilihan penggunaan RTOS (Real Time Operating System) adalah lebih mudahnya mendesain sebuah aplikasi dikarenakan dengan OS ini kita dapat memilah-milah berdasarkan task dan respon dari masing-masing task yang dibangun. CoOS adalah RTOS yang berbasis kepada prioritas task, sehingga task yang memiliki prioritas tinggi yang akan dijalankan dan "siap untuk dijalankan" yang akan dieksekusi terlebih dahulu, semakin rendah nilai prioritas artinya prioritasnya semakin tinggi atau penting. Dalam hal ini sistem personal tracking mempunyai 5 task yang menjadi pendukung sistem, antara lain :

Tabel 2. Prioritas Task Sistem Personal Tracking

\begin{tabular}{|l|c|l|}
\hline \multicolumn{1}{|c|}{ Task } & $\begin{array}{c}\text { Nilai } \\
\text { Prioritas }\end{array}$ & \multicolumn{1}{c|}{ Fungsi } \\
\hline \hline gtop_handler & 10 & Menangani data yang berasal dari modul GPS \\
\hline simcomtx_handler & 12 & Menangani pengiriman data ke GSM engine \\
\hline simcom_handler & 14 & State machine untuk proses komunikasi dengan GSM engine \\
\hline process_loop & 15 & Menangani proses pengiriman data \\
\hline lowestproc & 32 & Menunjukkan kesehatan sistem berupa led berkedip \\
\hline \hline
\end{tabular}

Sebagai saluran komunikasi antar task dipergunakan message queue. Jika suatu task sedang menunggu datangnya message maka task tersebut dalam kondisi tidak siap dan task dengan nilai prioritas dibawahnya yang siap akan dijalankan, jika 4 (empat) task dari 5 (lima) task dalam kondisi menunggu message maka lowestproc task yang akan dijalankan. Lowestproc ini dalam kondisi sleep setiap waktu tertentu kemudian aktif kembali guna mentoggle led. Jika sistem normal maka lowestproc ini pasti akan sempat dijalankan dan akan mengakibatkan led berkedip dengan periode yang tetap. Apabila sistem mulai overload maka periode kedip tersebut akan memanjang atau bahkan tidak berkedip sama sekali. Dalam kondisi semacam itu dapat disimpulkan bahwa sistem tidak benar.

Event-event utama dari personal tracking tersebut digenerate oleh interrupt (Interrupt Service Routine), dalam hal ini serial rx interrupt dari gps module dan gsm engine, guna keperluan tersebut firmware personal tracking mempunyai dua Interrupt Service Routine (ISR) untuk menangani data yang datang dari serial. Apabila satu frame data lengkap 
diterima dari gps module maka ISR akan mengirim message ke gtop_handler, dikarenakan task gtop_handler mempunyai prioritas paling tinggi maka akan langsung dieksekusi untuk mencatat data lokasi. Apabila satu frame dari gsm engine lengkap maka ISR akan mengirimkan message ke simcom_handler, jika tidak ada task dengan prioritas diatasnya yang siap maka akan dijalankan, tetapi jika terdapat task diatasnya yang siap atau sedang dijalankan maka akan menunggu sampai task-task tersebut menunggu kembali.

Pada bagian mikrokontroler, firmware yang mempunyai peranan penting yakni firmware yang mengakomodir proses perubahan data NMEA yang berasal dari GPS receiver ke format SMS yang nantinya akan diterima oleh pengamat. Pada Gambar 2. akan dijabarkan bagaimana alur proses perubahan data NMEA menjadi format SMS terjadi.

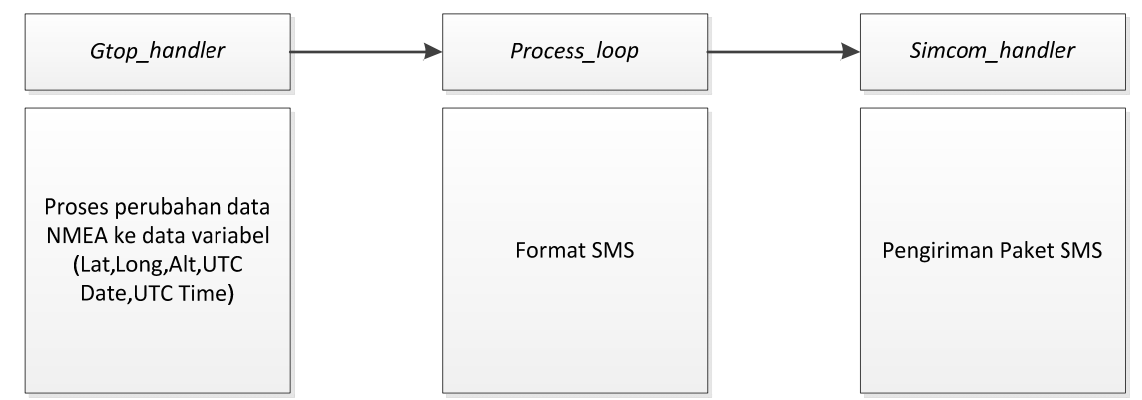

\section{Gambar 2. Alur Proses Perubahan Data NMEA Menjadi Format SMS}

Pada Gambar 2. diatas, dapat dijabarkan alur perubahan data NMEA menjadi format SMS.

a. gtop_handler task, data mentah NMEA yang berasal dari GPS receiver dipilah sesuai dengan kebutuhan sistem, format kalimat NMEA yang diproses adalah \$GPGGA dan \$GPRMC. Dalam format \$GPGGA mengandung data posisi yakni longitude, latitude, altitude, serta UTC time, sedangkan dalam format \$GPRMC mengandung data update RTC (Real Time Clock). Dengan kombinasi kedua format NMEA tersebut sistem telah sesuai dengan spesifikasi sistem yang akan dibangun (Tabel 1.). Alur kerja (flowchart) dapat dilihat pada Gambar 3.(a).

b. process_loop task, merupakan firmware utama dari sistem personal tracking ini, Data format NMEA yang telah dilakukan pemilahan pada task gtop_handler kemudian diteruskan ke proses selanjutnya yakni pengkonversian data koordinat posisi yang berupa data longitude serta data latitude ke dalam format Google Maps. Pada Gambar 3.(b) terdapat proses Send SMS (\$INIT, \$CHECKIN, \$PANIC) yang kesemua isi SMS telah berformat Google Maps.

c. simcom_handler task, dalam task ini hal yang dilakukan hanyalah proses melakukan pengiriman paket data SMS kepada pengamat. Pada Gambar 4. terlihat bagaimana alur kerja pengiriman paket SMS ke pengamat. 


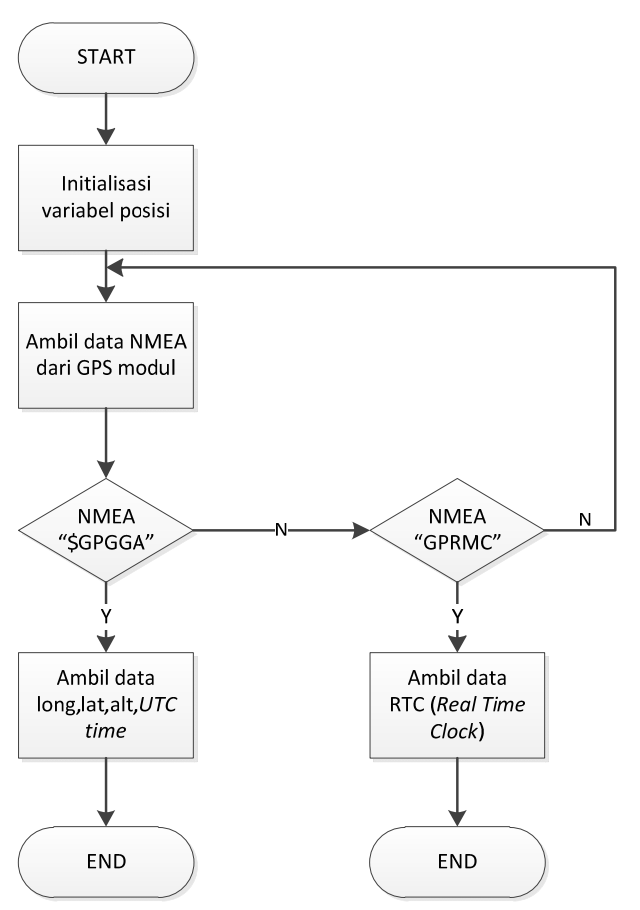

(a)

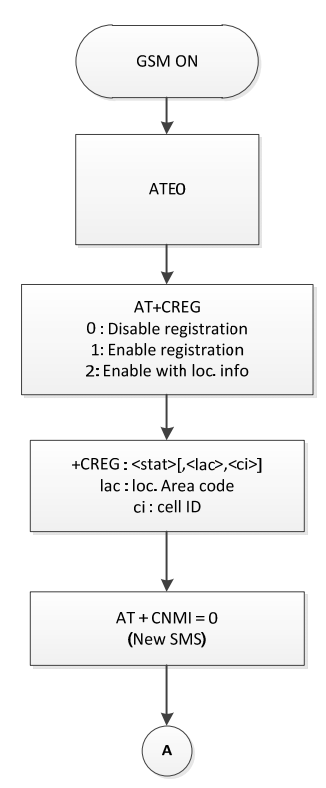

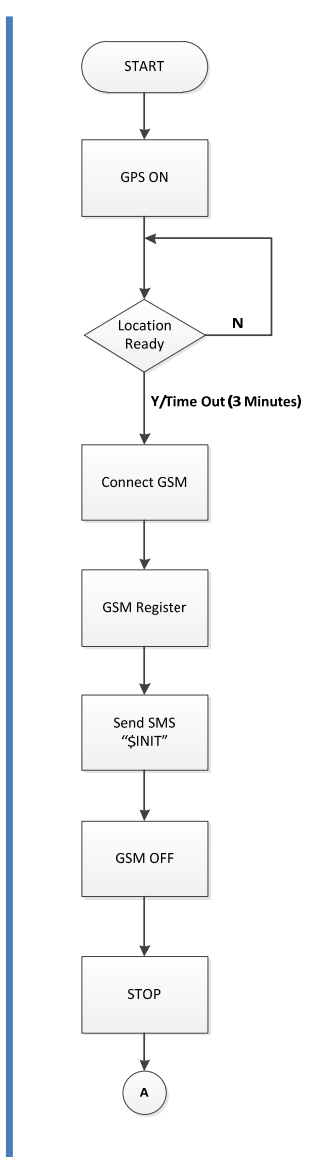

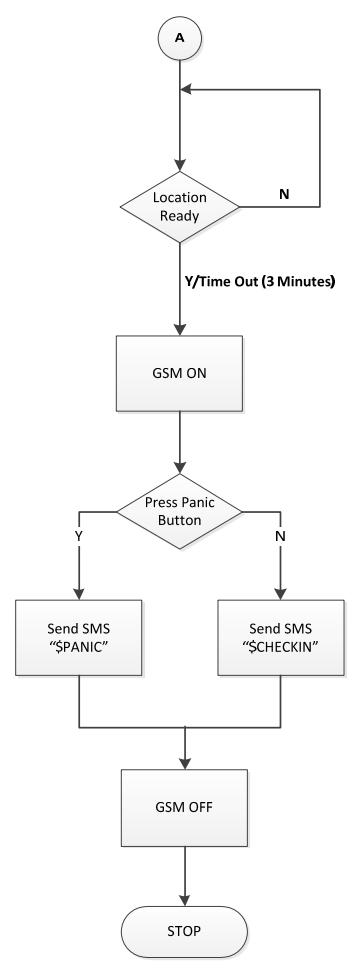

(b)

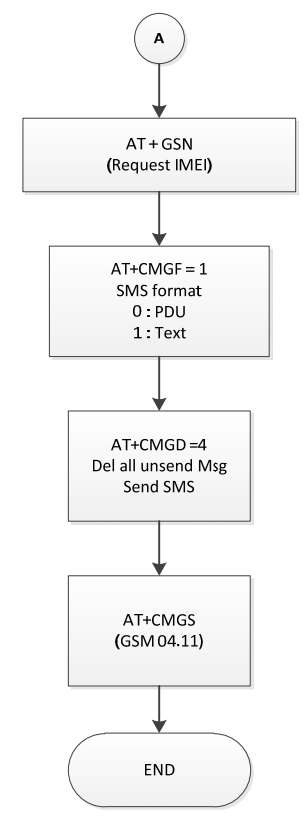

(c)

Gambar 3.(a) Flowchart firmware gtop_ handler (b)Flowchart firmware proccess_loop

(c) Flowchart firmware simcom_ handler 


\section{I MPLEMENTASI DAN PENGUJ I AN SI STEM}

Pengujian dilakukan guna mengetahui tingkat keberhasilan perangkat yang telah dirancang serta direalisasikan. Pengujian yang dilakukan yakni pengujian fungsional sistem personal tracking secara keseluruhan. Pada Gambar 4. menunjukkan Implementasi Perangkat keras personal tracking yang telah terintegrasi dengan firmware.
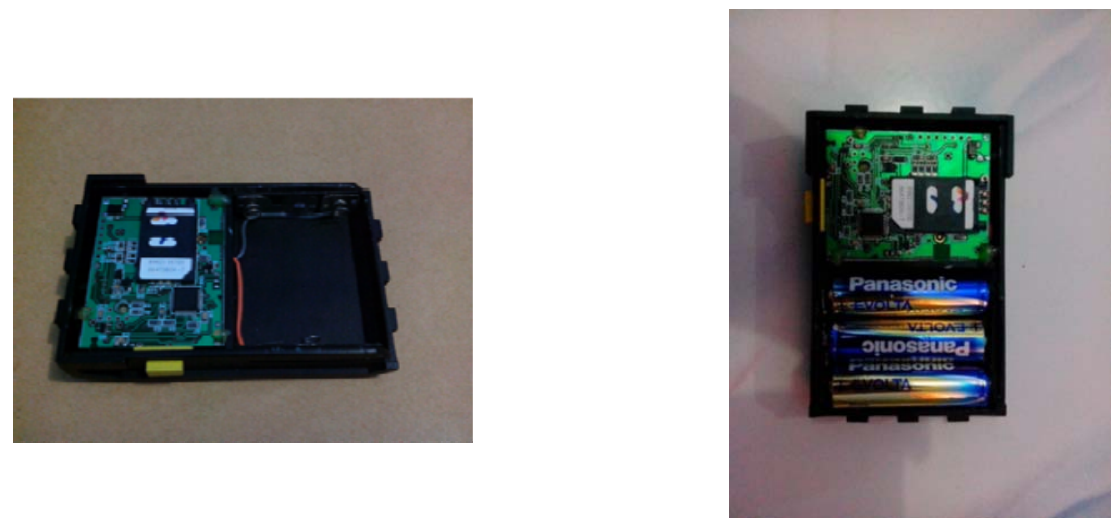

Gambar 4. Device Personal Tracking

\subsection{Pengujian Device Outdoor (Open-Sky)}

Pengujian device personal tracking di outdoor dilakukan di rooftop yang kondisinya tanpa terdapat penghalang, sehingga memungkinkan GPS receiver mendapat sinyal dari satelit GPS secara langsung. Pada Tabel 3. ditampilkan data pengujian device di outdoor.

Tabel 3. Data Pengujian Outdoor Device Personal Tracking

\begin{tabular}{|c|c|c|c|c|c|c|c|c|c|}
\hline \multirow{2}{*}{ No. } & \multirow{2}{*}{ UTC Date } & \multirow{2}{*}{ UTC Time } & \multirow{2}{*}{ GMT +7.00} & \multirow{2}{*}{$\begin{array}{l}\text { Message } \\
\text { Arrived }\end{array}$} & \multirow{2}{*}{ Delay } & \multirow{2}{*}{$\begin{array}{c}\text { Interval } \\
\text { Sending SMS } \\
\end{array}$} & \multicolumn{2}{|c|}{ Data Tracking } & \multirow{2}{*}{$\begin{array}{c}\text { Number of } \\
\text { Satellite }\end{array}$} \\
\hline & & & & & & & Latitude & Longitude & \\
\hline 1 & 210713 & 043159.000 & $11: 31: 59$ & $11: 32: 06$ & 00:00:07 & 0:00:00 & -6.90055 & 107.65267 & 11 \\
\hline 2 & 210713 & 043752.000 & $11: 37: 52$ & 11:37:58 & 00:00:06 & 0:05:52 & -6.90057 & 107.65269 & 9 \\
\hline 4 & 210713 & 044812.000 & 11:48:12 & 11:48:19 & $00: 00: 07$ & 0:05:14 & -6.90053 & 107.65267 & 12 \\
\hline 5 & 210713 & 045321.000 & $11: 53: 21$ & $11: 53: 28$ & 00:00:07 & 0:05:09 & -6.90056 & 107.65268 & 10 \\
\hline 6 & 210713 & 045830.000 & $11: 58: 30$ & $11: 58: 38$ & 00:00:08 & 0:05:10 & -6.90054 & 107.65266 & 10 \\
\hline 8 & 210713 & 050855.000 & $12: 08: 55$ & 12:09:06 & 00:00:11 & 0:05:13 & -6.90053 & 107.65266 & 10 \\
\hline 9 & 210713 & 051407.000 & $12: 14: 07$ & $12: 14: 17$ & $00: 00: 10$ & 0:05:11 & -6.90053 & 107.65263 & 12 \\
\hline 10 & 210713 & 051616.000 & $12: 16: 16$ & $12: 16: 25$ & 00:00:09 & 0:02:08 & -6.90058 & 107.65264 & 11 \\
\hline 11 & 210713 & 051712.000 & $12: 17: 12$ & $12: 17: 20$ & 00:00:08 & $0: 00: 55$ & -6.90058 & 107.65265 & 11 \\
\hline 12 & 210713 & 052221.000 & $12: 22: 21$ & $12: 22: 29$ & 00:00:08 & 0:05:09 & -6.90052 & 107.65263 & 10 \\
\hline & & & & Rata-Rata & 00:00:08 & 0:04:35 & & & \\
\hline
\end{tabular}

Dari data hasil pengujian device, pengamat dapat mengetahui posisi device berada dengan cara melakukan input kombinasi data koordinat latitude dan longitude ke aplikasi Google Maps. Setelah berhasil menginputkan data koordinat tersebut ke dalam Google Maps, barulah pengamat dapat mengetahui dimana device tersebut berada, sehingga proses pemantauan dan analisis dapat dilakukan dengan mudah. Pada Gambar 5. ditampilkan pointer-pointer hasil kombinasi masukan data koordinat pengujian outdoor terhadap device dalam tampilan Google Maps. 


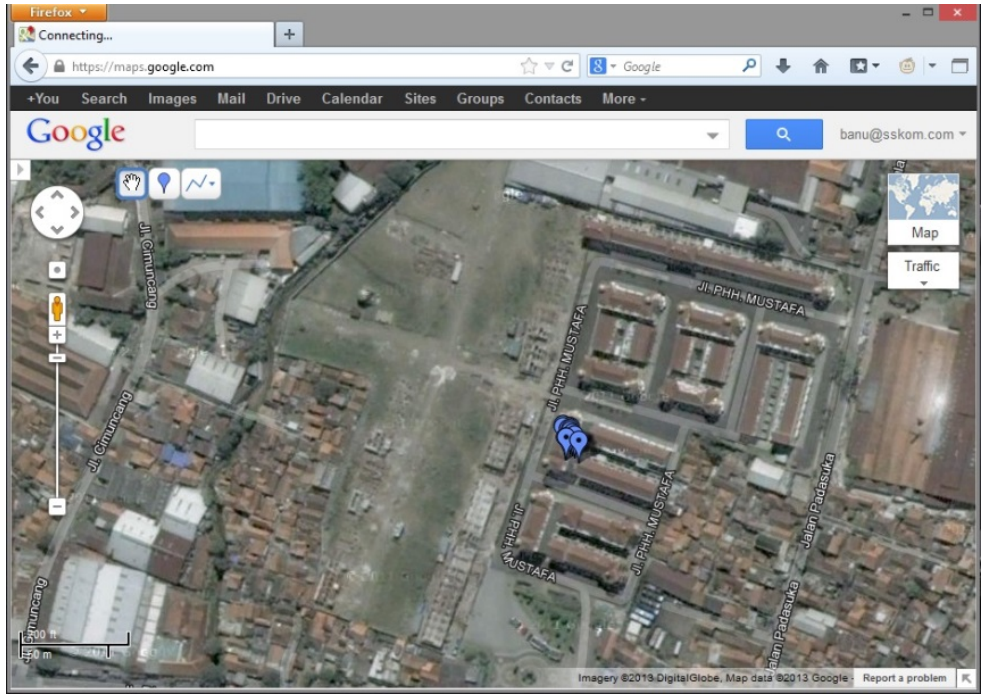

Gambar 5. Pointer Hasil Pengujian OutdoorTerhadap Device

Terlihat pada Gambar 5. pointer kombinasi data koordinat terlihat sangat rapat, hal ini dikarenakan device menangkap dengan sempurna sinyal GPS yang dipancarkan oleh satelit GPS. Hal ini sesuai dengan data sheet dari GPS receiver sendiri yakni jika posisi device berada di daerah open-sky maka akurasi posisinya \pm 2.5 - 3 meter (FGPMMOPA6B ref. Manual, 2011).

Pada Tabel 3. untuk data pengujian no 10,11 diberikan warna merah, hal ini dimaksudkan pada kondisi saat itu push button diaktifkan, atau dengan kata lain sistem mengirimkan sinyal secara tiba-tiba, diluar alur proses yang dirancang dalam sistem. Dapat terlihat interval sending SMS lebih cepat dibandingkan dengan data pengujian yang lain yakni berkisar $\pm 1-3$ menit. Data yang tertampil mendekati spesifikasi sistem yang dibuat, yakni jika terdapat interrupt dari push button maka interval pengiriman SMS menjadi lebih cepat berkisar \pm 2 - 3 menit.

\subsection{Pengujian Device Indoor}

Selain pengujian outdoor terhadap device, dalam penelitian ini dilakukan pula pengujian indoor terhadap device, diharapkan hasil yang didapat sama dengan hasil pengujian di outdoor. Pengujian dilakukan di lantai pertama gedung bertingkat 4 lantai (Gedung Elektro Itenas) yang kontur daerahnya memungkinkan timbul efek multipath, efek multipath sendiri adalah fenomena dimana sinyal dari satelit tiba di GPS receiver melalui dua atau lebih lintasan yang berbeda. Di lingkungan Itenas banyak sekali bidang reflektor yang menyebabkan multipath terjadi, bidang reflektor tersebut antara lain jalan, bangunan, dan gedung. (Abidin,1997) Pada Tabel 4. ditampilkan data pengujian device di indoor. 
Tabel 4. Data Pengujian Indoor Device Personal Tracking

\begin{tabular}{|c|c|c|c|c|c|c|c|c|c|}
\hline \multirow{2}{*}{ No. } & \multirow{2}{*}{ UTC Date } & \multirow{2}{*}{ UTC Time } & \multirow{2}{*}{ GMT + 7.00} & \multirow{2}{*}{$\begin{array}{l}\text { Message } \\
\text { Arrived }\end{array}$} & \multirow{2}{*}{ Delay } & \multirow{2}{*}{$\begin{array}{c}\text { Interval } \\
\text { Sending SMS }\end{array}$} & \multicolumn{2}{|c|}{ Data Tracking } & \multirow{2}{*}{$\begin{array}{c}\text { Number of } \\
\text { Satellite }\end{array}$} \\
\hline & & & & & & & Latitude & Longitude & \\
\hline 1 & 230713 & 065106.000 & 01:51:06 & 01:54:38 & $00: 03: 32$ & $00: 00: 00$ & -6.89773 & 107.63600 & 6 \\
\hline 3 & 230713 & 070127.000 & 02:01:27 & 02:04:32 & 00:03:05 & $00: 02: 58$ & -6.89788 & 107.63589 & 0 \\
\hline 4 & 230713 & 070424.000 & 02:04:24 & 02:09:07 & $00: 04: 43$ & $00: 04: 35$ & -6.89788 & 107.63589 & 0 \\
\hline 5 & 230713 & 070859.000 & 02:08:59 & 02:14:11 & $00: 05: 12$ & 00:05:04 & -6.89788 & 107.63589 & 0 \\
\hline 8 & 230713 & 072215.000 & $02: 22: 15$ & $02: 25: 46$ & $00: 03: 31$ & $00: 03: 20$ & -6.89731 & 107.63598 & 4 \\
\hline 9 & 230713 & 072516.000 & $02: 25: 16$ & $02: 32: 37$ & $00: 07: 21$ & 00:06:51 & -6.89769 & 107.63578 & 3 \\
\hline 10 & 230713 & 073227.000 & $02: 32: 27$ & $02: 37: 44$ & 00:05:17 & 00:05:07 & -6.89772 & 107.63582 & 0 \\
\hline 11 & 230713 & 073736.000 & $02: 37: 36$ & $02: 40: 53$ & 00:03:17 & 00:03:09 & -6.89772 & 107.63582 & 0 \\
\hline 12 & 230713 & 074045.000 & 02:40:45 & 02:42:03 & 00:01:18 & 00:01:10 & -6.89742 & 107.63592 & 3 \\
\hline 16 & 230713 & 075430.000 & 02:54:30 & 02:59:02 & $00: 04: 32$ & $00: 04: 23$ & -6.89707 & 107.63605 & 3 \\
\hline 17 & 230713 & 075853.000 & 02:58:53 & 03:04:16 & $00: 05: 23$ & $00: 05: 14$ & -6.89718 & 107.63589 & 4 \\
\hline 18 & 230713 & 080407.000 & 03:04:07 & 03:05:15 & 00:01:08 & 00:00:59 & -6.89734 & 107.63577 & 1 \\
\hline 19 & 230713 & 080504.000 & 03:05:04 & 03:06:18 & 00:01:14 & 00:01:03 & -6.89704 & 107.63603 & 3 \\
\hline 20 & 230713 & 081056.000 & 03:10:56 & 03:11:04 & 00:00:08 & $00: 04: 46$ & -6.89810 & 107.63597 & 5 \\
\hline & & & & Rata - Rata & 00:03:56 & 00:04:10 & & & \\
\hline
\end{tabular}

Proses selanjutnya guna mempermudah pengamatan, langkah-langkah yang dilakukan sama dengan langkah yang dilakukan pada saat pengujian outdoor terhadap device yakni melakukan input kombinasi data koordinat latitude dan longitude ke aplikasi Google Maps.

Pada Gambar 6. ditampilkan pointer-pointer hasil kombinasi masukan data koordinat pengujian indoor terhadap device dalam tampilan Google Maps.

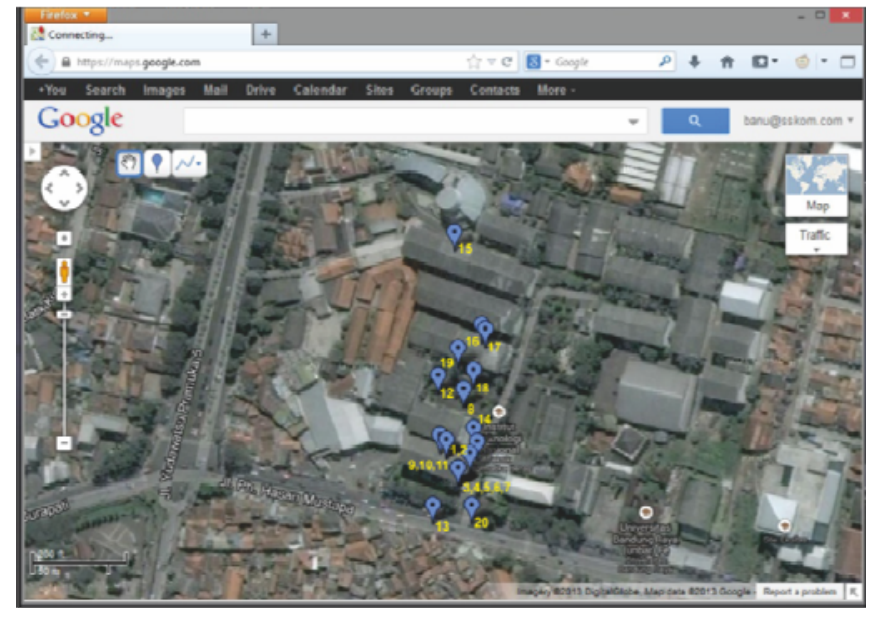

\section{Gambar 6. Pointer Hasil Pengujian IndoorTerhadap Device}

Terlihat pada Gambar 6. pointer kombinasi data koordinat terlihat banyak sekali yang menjauhi device, hal ini dikarenakan device menangkap tidak sempurna sinyal GPS yang dipancarkan oleh satelit GPS. Telah terbukti bahwa efek multipath ada pada saat pengujian.

Pada Tabel 4. terlihat jumlah satelit yang diperoleh tidak sebanyak waktu pengujian outdoor terhadap device, hal ini disebabkan device berada didalam gedung. Waktu delay yang didapat antara waktu device memperoleh data posisi dengan waktu SMS sampai ke pengamat dapat dikatakan cukup lama, hal ini disebabkan operator yang dipergunakan 
untuk menjembatani antara device dengan pengamat lemah, dalam artian sinyal yang diterima operator tersebut sangat lemah, hal ini yang mengakibatkan keterlambatan dalam pengiriman paket SMS.

Pengaktifan push button terlihat lebih sering digunakan, hal ini dimaksudkan apakah sistem mampu menghandle interrupt dengan intensitas yang cukup sering bersamaan dengan sistem mencari sinyal GPS. Hasil yang diperoleh yakni berkisar $\pm 1-4$ menit.

\subsection{Tampilan SMS dari Device ke User}

Berikut adalah tampilan SMS yang berisikan data koordinat posisi dari GPS receiver.

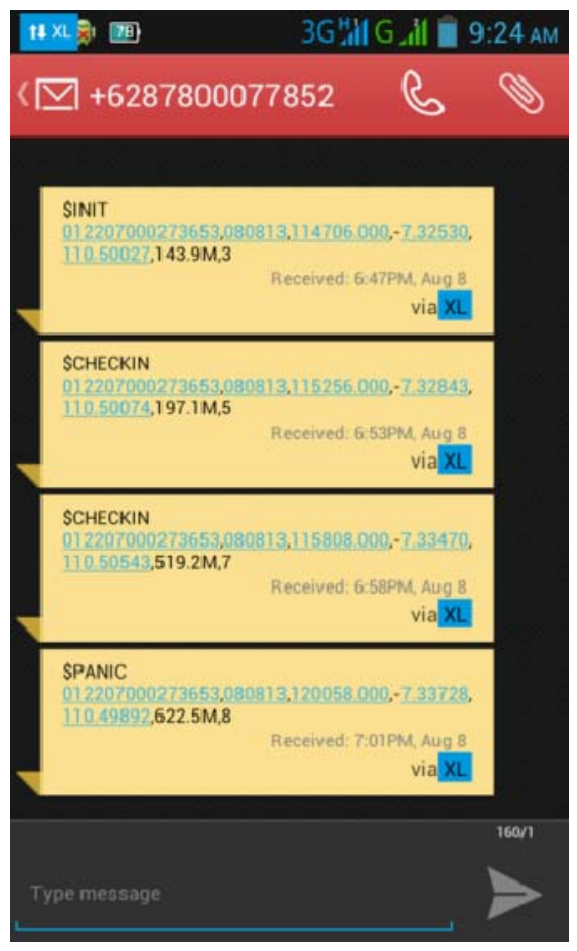

\section{Gambar 7. Tampilan SMS dari Device ke User}

Pada Gambar 7. Terlihat isi SMS yang berasal dari device personal tracking yang menunjukkan koordinat posisi device. Dengan Tabel 5. dijabarkan isi tampilan SMS yang berasal dari device.

Tabel 5. Struktur Tampilan SMS

\begin{tabular}{|l|c|}
\hline \multicolumn{1}{|c|}{ Nama } & Contoh Struktur Tampilan SMS \\
\hline \hline Message ID & \$INIT \\
\hline IMEI & 012207000273653 \\
\hline UTC Date & 230713 \\
\hline UTC Time & 700424.000 \\
\hline Latitude & -6.89788 \\
\hline Longitude & 107.63589 \\
\hline Altitude & 519.2 \\
\hline Number of Satellite & 8 \\
\hline
\end{tabular}




\section{KESI MPULAN DAN SARAN}

\subsection{Kesimpulan}

Dari hasil keseluruhan rancangan, implementasi, serta pengujian terhadap sistem, dapat disimpulkan bahwa :

a. Sistem personal tracking telah berhasil direalisasikan, sistem ini mampu mengirimkan tiga jenis format SMS sesuai dengan spesifikasi awal sistem yakni \$INIT, \$CHECKIN, serta \$PANIC.

b. Interrupt yang berasal dari push button berhasil dieksekusi, sehingga device berhasil mengirimkan SMS dengan format \$PANIC. Interval pengiriman SMS \$PANIC berkisar $\pm 1-4$ menit.

c. Pada kondisi open-sky GPS receiver berfungsi sangat baik dalam menerima sinyal GPS yang berasal dari satelit GPS. Terlihat pointer-pointer hasil inputan kombinasi koordinat posisi tidak menjauh dari posisi device berada, hal ini sesuai dengan data sheet GPS receiver sendiri bahwa jika dalam kondisi open-sky akurasi posisi tidak melebihi 3 meter.

d. Interval pengiriman SMS berkala atau SMS berformat $\$ C H E C K I N$ sesuai dengan spesifikasi awal yakni berkisar pada $\pm 4-5$ menit, kondisi operator yang dipergunakan juga mempunyai peranan penting dalam kecepatan pengiriman SMS.

\subsection{Saran}

a. Tindak lanjut yang dapat dijadikan acuan pengembangan sistem yakni, perlu adanya perhitungan lebih detail mengenai penerimaan sinyal GPS oleh GPS receiver sehingga mendapatkan hasil koordinat posisi lebih akurat dan valid jika berada di daerah yang mudah timbul efek multipath.

b. Perlu adanya penambahan hardware yakni gyroscope serta accelerometer, serta penambahan algoritma kalman filter, sehingga posisi device lebih presisi.

\section{DAFTAR RUJ UKAN}

Abidin, H. Z. DR. (2000). Penentuan Posisi Dengan GPS dan Aplikasinya. Jakarta: PT.Pradnya Paramita.

Bin Mohammad, Shuhairie. (2008). GPS Navigation System. Malaysia: Universiti Malaysia Pahang.

Marinto N.,Ingot. (2007) Sistem Navigasi Helikopter Berdasarkan Data Posisi Secara Telemetri. Jakarta: Universitas Indonesia.

Nugroho, Ari. (2008) Rancang Bangun dan Pemrograman Sistem Transmisi Data GPS Menggunakan Teknologi CSD Sebagai Aplikasi Sistem Penjejakan Posisi Berbasis Mikrokontroler AVR-ATMEGA 8535. J akarta: Universitas Indonesia. 